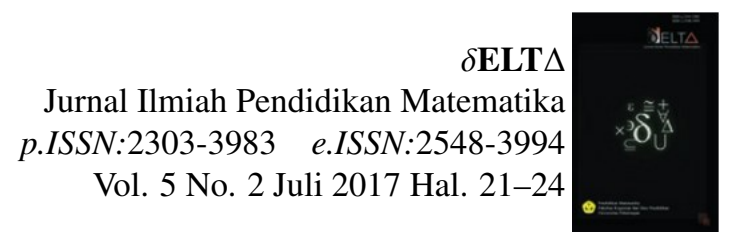

\title{
PENERAPAN MODEL PEMBELAJARAN MATEMATIKA MENGGUNAKAN MODEL SAVI DAN VAK PADA MATERI HIMPUNAN TERHADAP PRESTASI BELAJAR SISWA KELAS VII
}

\author{
Nurina Kurniasari Rahmawati ${ }^{\mathrm{a}}$ \\ a STKIP Kusuma Negara, Nurinakr@gmail.com
}

\begin{abstract}
This study aimed to determine whether the SAVI learning model provided better mathematics learning achievement than the VAK and ceramah learning models. The population of this research was VII second semester students of SMP N 3 Wonosobo, which amounts to 130 students. The sample of this research was 91 students. Sampling by cluster random sampling technique. Instrument of data collection used documentation and test. Data analysis used One Way Variance Analysis with Same Cells. The variance analysis test gave the result that the SAVI learning model provides the same mathematics learning achievement with the VAK learning model, the VAK learning model provides better mathematics learning achievement from the ceramah learning model, and the SAVI learning model provides better mathematics learning achievement from the ceramah learning model on himpunan material.
\end{abstract}

Keywords: Model SAVI, Model VAK, Ceramah, Prestasi belajar

\section{Pendahuluan}

Dalam dunia pendidikan Indonesia, matematika merupakan salah satu mata pelajaran yang menjadi mata pelajaran wajib. Hal ini dikarenakan matematika mempunyai peranan penting dalam menyelesaikan masalah yang berkaitan dengan kehidupan sehari-hari manusia. Hal ini sesuai dengan pendapat Muijs dan Reynolds (3), hal.333) bahwa dari hasil penelitian yang dilakukan oleh The Basic Skill Agency, membuktikan pentingnya matematika di dalam kehidupan sehari-hari orang dewasa, kurangnya keterampilan numerasi mengakibatkan pengangguran dan penghasilan yang rendah pada orang dewasa, yang melampaui efek kemampuan baca-tulis yang rendah pada orang-orang dewasa yang sama. Demikian juga Ojose (4) menyatakan bahwa seseorang yang mempunyai literasi matematis dapat menafsirkan data, memecahkan masalah sehari-hari, alasan dalam situasi numerik, grafis, dan geometris, serta berkomunikasi dengan menggunakan matematika.

Menyadari akan pentingnya matematika, telah banyak dilakukan upaya meningkatkan kualitas pembelajaran matematika di sekolah. Upaya ini dapat dilihat dari langkah penyempurnaan kurikulum yang terus dilakukan, peningkatan kualitas guru bidang studi, penyediaan dan pembaharuan buku ajar, penyediaan dan perlengkapan alat-alat pelajaran (laboratorium) matematika, pengembangan pendekatan yang lebih relevan dan efektif mencapai tujuan pembelajaran matematika, dan masih banyak usaha lain yang ditempuh untuk memperbaiki pencapaian hasil belajar matematika di sekolah. Namun hasil belajar yang diperoleh siswa belum menampakkan hasil yang sesuai dengan harapanProses kegiatan belajar mengajar perlu diupayakan suatu hubungan yang baik antara siswa dan guru sehingga akan terjadi interaksi dan komunikasi yang baik. Fakta yang terjadi di lapangan adalah guru dianggap sumber belajar yang paling benar. Proses pembelajaran yang terjadi memposisikan siswa sebagai pendengar ceramah guru, akibatnya proses pembelajaran cenderung membosankan dan menjadikan siswa malas dalam belajar. Sikap siswa yang malas tersebut ternyata tidak hanya terjadi pada mata pelajaran tertentu saja tetapi hampir pada semua mata pelajaran termasuk mata pelajaran matematika.

Banyak faktor yang mempengaruhi rendahnya prestas belajar matematika pada siswa baik faktor internal maupun faktor eksternal. Faktor internal yang mempengaruhi hasil belajar siswa salah satunya adalah kemampuan komunikasi matematis siswa dalam mempelajari materi pelajaran yang diberikan, sedangkan faktor eksternal salah satunya adalah cara guru mengajar, atau model pembelajaran yang digunakan oleh guru dalam pembelajaran di kelas. Upaya mengantisipasi masalah tersebut, maka perlu dicarikan model yang tepat dalam pembelajaran matematika. Menurut Slameto (6, hal.65) suatu model pembelajaran mempunyai peranan penting karena menentukan berhasil tidaknya pembelajaran yang diinginkan. Para guru berusaha memilih strategi pembelajaran yang cocok untuk diterapkan kepada siswanya. Pemilihan strategi pembelajaran yang akan digunakan dalam proses pembelajaran harus berorientasi pada tujuan pembelajaran yang akan dicapai, selain itu juga harus disesuaikan dengan materi, karakteristik peserta didik, serta kondisi dimana proses pembelajaran tersebut akan berlangsung. Para guru juga terus menerus berusaha menyusun dan menerapkan berbagai model yang bervariasi agar siswa 
tertarik dan bersemangat dalam belajar matematika. Beberapa model pembelajaran bisa membuat siswa menjadi aktif. Salah satunya adalah melalui pendekatan SAVI (Somatis, Auditori, Visual, Intelektual). Menurut Meier (2, hal.91), model pembelajaran Somatis Auditori Visual dan Intelektual (SAVI) menggabungkan gerakan fisik dengan aktivitas intelektual dengan penggunaan semua indra dapat berpengaruh besar dalam pembelajaran. Berikutnya adalah model pembelajaran VAK ( Visualization, Auditory, Kinestetic) model pembelajaran VAK merupakan gaya yang menggunakan 3 macam sensori dalam menerima informasi yaitu penglihatan, pembelajaran akn berlangsung secara efektif dan efisien dengan memperhatikan ketiga hal tersebut. Dengan menerapkan VAK setiap siswa akan terpenuhi kebutuhannya sehingga mereka termotivasi dalam pembelajaran Matematika.

Pembelajaran matematika dengan menggunakan model pembelajaran yang tepat dapat mendorong tumbuhnya rasa senang siswa terhadap pelajaran. Selain itu juga dapat menumbuhkan semangat dalam diri siswa dalam mengerjakan tugas dan memahami pelajaran, sehingga memungkinkan siswa mencapai prestasi belajar yang lebih baik. Tujuan dari penelitian ini adalah untuk mengetahui apakah prestasi belajar matematika siswa yang menggunakan model pembelajaran SAVI memberikan prestasi belajar yang lebih baik dari model pembelajaran VAK model pembelajaran tipe SAVI memberikan prestasi belajar yang lebih baik dari model Ceramah dan model pembelajaran VAK memberikan prestasi belajar yang lebih baik dari model pembelajaran ceramah.

\section{Metodologi Penelitian}

Jenis penelitian yang akan digunakan dalam penelitian ini adalah penelitian kuantitatif dengan menggunakan metode penelitian eksperimen semu. Menurut Setyosari (5, hal.42), penelitian eksperimen semu merupakan penelitian yang dimaksudkan untuk mengetahui ada tidaknya akibat dari sesuatu yang dikenakan pada subjek selidik. Populasi dalam penelitian ini adalah semua siswa kelas VII SMP Negeri 3 Wonosobo Tahun Pelajaran 2016/2017. Jumlah populasi sebanyak 135 siswa yang terbagi menjadi lima kelas. Mengingat populasi dari penelitian ini cukup banyak yaitu semua siswa kelas VII SMP Negeri 3 Wonosobo Tahun Pelajaran 2016/2017 yang berjumlah 135 siswa dan terbagi menjadi lima kelas yaitu kelas VIIA, VIIB, VIIC, VIID, dan VIIE karena populasi dianggap memiliki karakteristik yang sama dari masing-masing kelas, maka sampel diambil secara cluster random sampling, yaitu sampel diambil secara acak dari kelima kelas tersebut sehingga diperoleh kelas VIIC, kelas VIID dan kelas VIIA dengan rincian satu kelas sebagai kelas eksperimen I yaitu kelas VII B sebanyak 31 siswa yang dikenakan model pembelajaran SAVI, satu kelas sebagai kelas eksperimen II yaitu kelas VII A sebanyak 30 siswa yang dikenakan model pembelajaran VAK dan satu kelas lagi sebagai kelas kontrol yaitu kelas VII C sebanyak 31 menggunakan model pembelajaran ceramah. Teknik yang digunakan untuk mengumpulkan data dalam penelitian ini ada dua macam yaitu dokumentasi dan tes.

Dalam penelitian ini metode dokumentasi digunakan untuk mengambil data yang berupa nilai, yaitu nilai ujian akhir semester ganjil kelas VII tahun pelajaran 2016/2017 pada pelajaran matematika. Data tersebut digunakan untuk melihat apakah kelompok eksperimen I, kelompok eksperimen II, dan kelompok kelas kontrol, dalam keadaan seimbang atau tidak. Sedangkan tes yang dibuat dalam penelitian ini berisi tentang materi sub pokok bahasan garis dan sudut. Menurut Suharsimi Arikunto (1) hal.203), instrumen penelitian adalah alat atau fasilitas yang digunakan peneliti dalam mengumpulkan data agar pekerjaannya lebih mudah dan hasilnya lebih baik. Instrumen yang digunakan dalam penelitian ini adalah soal tes prestasi pada sub pokok bahasan garis dan sudut berupa soal tipe pilihan ganda. Sebelum soal tes prestasi diberikan pada sampel, terlebih dahulu soal tes diujicobakan untuk mengetahui tingkat kesukaran dan daya pembeda soal serta untuk mengetahui apakah soal yang akan digunakan tersebut valid dan reliabel atau tidak. Sebelum sampel diberi perlakuan maka perlu di analisis dahulu melalui uji normalitas data awal, uji homogenitas data awal, dan uji keseimbangan, hal ini dilakukan supaya sampel berasal dari titik awal yang sama. Setelah diberi perlakuan juga harus di uji normalitas data akhir dan homogenitas data akhir, hal ini dalakukan sebagai syarat untuk dapat menggunakan statistik parametrik yaitu uji hipotesis analisis variansi satu jalan sel tak sama. Baik uji normalitas awal maupun akhir menggunakan metode Lillifors, sedangkan uji homogenitas awal maupun akhir menggunakan uji Bartlett. Analisis data menggunakan uji statistik parametrik yaitu uji yaitu uji hipotesis analisis variansi satu jalan sel tak sama.

\section{Hasil dan Pembahasan}

Pada uji normalitas data awal menunjukkan bahwa kemampuan awal siswa untuk kelompok eskperimen I, kelompok eksperimen II maupun Kelompok eksperimen III berdistribusi normal dan pada uji homogenitas yang menunjukkan bahwa ketiga sampel homogen, Kemudian dilakukan uji keseimbangan menggunakan uji hipotesis analisis variansi satu jalan sel tak sama dengan taraf signifikansi 0.05 yang menunjukkan bahwa kedua kelompok sampel mempunyai kemampuan awal yang sama. Hasil uji keseimbangan dengan menggunakan uji hipotesis analisis variansi dan taraf signifikan $\alpha=0.05$ diperoleh nilai uji $\mathrm{F}$ ( $F_{\text {obs }}$ ) sebesar 1.565 dengan nilai tabel $F_{0.05 ; 2,91}$ sebesar 3.11, dengan $D K=\{F \mid F>3.11\}$, keputusan Uji nya : $H_{0}$ diterima, sehingga dapat disimpulkan bahwa antara ketiga kelompok dalam keadaan seimbang.

Tes prestasi belajar matematika tersebut, sebelumnya telah diuji cobakan di kelas lain yang sama kemampuannya dengan ketiga kelas yang menjadi sampel yaitu kelas VII D. Kemudian dilakukan uji validitas isi yang 
telah divalidasi oleh 3 orang validator pada soal tes hasilbelajar, dan keduanya telah dinyatakan valid, kemudian diuji tingkat kesukaran, daya pembeda dan uji reliabilitas, sehingga diperoleh bahwa tes tersebut reliabel. Hasil dari tes prestasi belajar matematika kedua kelompok dilakukan uji normalitas, uji homogenitas dan uji hipotesis. Dari uji normalitas dan uji homogenitas menunjukkan bahwa kedua kelompok berdistribusi normal dan tidak ada perbedaan variansi atau homogen. Dari hasil uji hipotesis menggunakan distribusi F dan taraf signifikan $\alpha=0.05$ diperoleh nilai uji $\mathrm{F}\left(F_{\text {obs }}\right)$ sebesar 8.005 dengan nilai tabel $F_{0.05 ; 2,91}$ sebesar 3.11, dengan $D K=\{F \mid F>3.11\}$. Karena nilai $t_{\mathrm{obs}} \in D K$ maka $H_{0}$ ditolak, hal ini berarti tidak benar bahwa ketiga model pembelajaran tersebut memberikan prestasi belajar yang sama. Setelah dalam keputusan uji $H_{0}$ ditolak, maka untuk menentukan model pembelajaran manakah yang lebih baik dilakukan uji lanjut pasca anava yaitu uji komparasi ganda dengan metode Scheffe.

Tabel 1. Rangkuman Komparasi Ganda

\begin{tabular}{cccc}
\hline$H_{\mathbf{0}}$ & $F_{\text {obs }}$ & $2 F_{\alpha}$ & Keputusan Uji \\
\hline$\mu_{1}=\mu_{2}$ & 1.792 & $(2)(3.11)=6.22$ & $H_{0}$ diterima \\
$\mu_{2}=\mu_{3}$ & 15.428 & $(2)(3.11)=6.22$ & $H_{0}$ ditolak \\
$\mu_{1}=\mu_{3}$ & 6.814 & $(2)(3.11)=6.22$ & $H_{0}$ ditolak \\
\hline
\end{tabular}

Dengan membandingkan $F_{\text {obs }}$ dengan daerah kritis, terlihat bahwa $\mu_{1}$ dengan $\mu_{2} H_{0}$ diterima, $\mu_{2}$ dengan $\mu_{3} H_{0}$ ditolak, dan $\mu_{1}$ dengan $\mu_{3} H_{0}$ ditolak berarti yang terdapat perbedaan signifikan adalah $\mu_{2}$ dengan $\mu_{3}$ dan $\mu_{1}$ dengan $\mu_{3}$. Sedangkan, rerata marginalnya pada hasil belajar matematika yang menggunakan model pembelajaran SAVI diperoleh 70.129, rerata hasil belajar matematika yang menggunakan model pembelajaran VAK diperoleh 74.226, dan rerata hasil belajar matematika yang menggunakan model pembelajaran ceramah diperoleh 62.129. Dengan melihat rerata marginalnya tersebut maka dapat diartikan (1) pada $H_{0}: \mu_{1}=\mu_{2}$ keputusan ujinya $H_{0}$ diterima melihat rerata marginalnya pada model pembelajaran SAVI sebesar 70.129 dan rerata marginal model pembelajarannya VAK sebesar 74.226 melihat dari nilai rerata SAVI memiliki nilai yang lebih baik dibandingkan dengan VAK tetapi karena hasil komparasi ganda $H_{0}$ diterima maka dapat disimpulkan model pembelajaran SAVI menghasilkan hasil belajar yang sama baik dengan VAK walaupun nilai rerata marginal model pembelajaran SAVI lebih besar dibandingkan dengan VAK. (2) pada $H_{0}: \mu_{2}=\mu_{3}$ keputusan ujinya $H_{0}$ ditolak. Melihat rerata marginal pada model pembelajaran VAK sebesar 74.226, dan rerata marginal pada model pembelajaran ceramah sebesar 62.129, yang artinya rerata model pembelajaran VAK lebih besar dari rerata marginal model pembelajaran ceramah, sehingga model pembelajaran VAK menghasilkan hasil belajar yang lebih baik dari model pembelajaran ceramah. (3) pada $H_{0}: \mu_{1}=\mu_{3}$ keputusan ujinya Ho ditolak. Melihat rerata marginal pada model pembelajaran SAVI sebesar 70.129 dan rerata marginal pada model pembelajaran ceramah sebesar 62.129, yang artinya rerata model pembelajaran SAVI lebih besar dari rerata marginal model pembelajaran ceramah, sehingga model pembelajaran SAVI menghasilkan hasil belajar yang lebih baik dari model pembelajaran ceramah.

Hasil penelitian ini sesuai dengan hipo VAK memberikan hasil belajar yang lebih baik dari model pembelajaran ceramah, dan hipotesis ketiga yang menyatakan bahwa siswa penggunaan model pembelajaran SAVI memberikan hasil belajar yang lebih baik dari model pembelajaran ceramah.

Ada satu hasil penelitian yang tidak sesuai dengan hipotesis ke (1) yang telah dirumuskan sebelumnya yakni hipotesis yang menyatakan bahwa penggunaan model pembelajaran SAVI memberikan hasil belajar yang lebih baik dari VAK. Tidak sesuainya hipotesis Tidak sesuainya hipotesis dalam penelitian ini dengan hasil penelitian lebih disebabkan karena pengaruh variabel-variabel luaran yang tidak bisa dikontrol oleh peneliti. Meskipun kemungkinan besar variabel tersebut sebenarnya dapat mempengarui data penelitian. Pengaturan jadwal yang tidak proporsional antar sekolah diduga menjadi faktor paling dominan penyebab hipotesis ini tidak terbukti. Hal tersebut dikarenakan pada saat penelitian dilakukan, jadwal mengajar pada tiga sekolah yang berbeda ada yang berbenturan, sehingga peneliti tidak bisa fokus pada pembelajaran di kelas, yang mengakibatkan kurangnya perhatisn siswa untuk fokus pada pembelajaran. Hal ini dimungkinkan menjadi penyebab siswa tidak optimal dalam mengikuti pelajaran sehingga hasilnya tidak bisa maksimal. Sementara ketika penelitian ini dilakukan peneliti tidak dipebolehkan membuat jadwal sesuai kehendak peneliti.

\section{Kesimpulan dan Saran}

Berdasarkan hasil penelitian ini, penerapan model pembelajaran SAVI memberikan prestasi yang sama baik dengan siswa yang menggunakan model pembelajaran VAK, dan prestasi belajar siswa yang menggunakan model pembelajaran SAVI dan model pembelajaran VAK mampu memberikan prestasi belajar yang lebih baik di bandingkan dengan model pembelajaran ceramah pada materi Himpunan kelas VII Tahun Ajaran 2016/2017. Dari hasil penelitian ini, maka perlu kiranya penulis memberikan saran kepada pihak-pihak yang berkaitan dengan masalah penelitian ini. 
1. Dalam proses pembelajaran matematika dengan menggunakan model pembelajaran SAVI dan VAKagar dapat mencapai hasil maksimal, maka guru perlu memperhatikan hal-hal seperti keaktifan siswa, serta kemampuan guru dalam membantu siswa yang mengalami kesulitan pada saat kegiatan diskusi.

2. Dalam proses pembelajaran matematika, hendaknya guru juga memperhatikan komponen-komponen yang mempengaruhi proses pencapaian prestasi belajar siswa, misalnya minat belajar, motivasi, kemampuan awal, dan kedisiplinan siswa. Sehingga dapat dicari alternatif dalam membentuk pola pembelajaran dalam kelas yang dapat mengakibatkan prestasi belajar matematika siswa meningkat.

3. Kepada peneliti yang lain mengadakan penelitian lebih lanjut guna menemukan faktor-faktor lain yang dapat meningkatkan prestasi belajar matematika siswa, selain kreatifitas belajar matematika siswa.

\section{Pustaka}

[1] Arikunto, S., 2010. Prosedur Penelitian Suatu Pendekatan Praktik. Rineka Cipta.

[2] Meier, D., 2002. The Accelarated Learning Hand Book. Kaifa.

[3] Muijs, Reynolds, 2008. Effective Teaching (Teori dan Aplikasi). Pustaka Belajar.

[4] Ojose, B., 2011. Mathematics Literacy: Are We Able To Put The Mathematics We Learn Into Everyday Use? J. Math. Educ. (c) Educ. $4(1), 89-100$.

URL http://educationforatoz.com/images/8.Bobby_Ojose_--_Mathematics_Literacy_Are_We_Able_To_Put_The_ Mathematics_We_Learn_Into_Everyday_Use.pdf

[5] Setyosari, P., 2012. Metode Penelitian Pendidikan dan Pengembangan. Kencana Prenada Media Group.

[6] Slameto, 2010. Belajar dan Faktor-faktor yang Mempengaruhinya. Rineka Cipta. 